www.jmscr.igmpublication.org Impact Factor 5.244

Index Copernicus Value: 5.88

ISSN (e)-2347-176x ISSN (p) 2455-0450

crossref DOI: _http://dx.doi.org/10.18535/jmscr/v4i5.16

Journal Of Medical Science And Clinical Research

\title{
Ultrasound Evaluation of Dengue Fever
}

\author{
Authors \\ V Sravani $^{1}$, Sandeep K ${ }^{1}$, H.R Nagrale ${ }^{2}$, S.Veeraswamy ${ }^{3}$ \\ ${ }^{1}$ Postgraduate, Department of Radio-Diagnosis, Mamata Medical College, Khammam \\ ${ }^{2}$ Professor \& Head, Department of Radio-Diagnosis, Mamata Medical College, Khammam \\ ${ }^{3}$ Professor, Department of Radio-Diagnosis, Mamata Medical College, Khammam
}

Corresponding Author

Dr V.Sravani

Post Graduate, Department of Radio-Diagnosis, Mamata Medical College, Khammam

Email: sravz.vemula@gmail.com

\section{ABSTRACT}

This study is to determine whether ultrasound is an important adjuvant to clinical and laboratory profile: to predict prognosis and assessing severity of disease with platelet correlation. ultrasonic variations seen in various age groups were studied. we conducted a prospective study in seriologically positive 115 cases of dengue fever between June and December 2015 were refered for USG abdomen and USG thorax.

KEYWORDS: Dengue fever, ultrasound, ascities, gall bladder odema, pleural effusion.

\section{INTRODUCTION}

Dengue infections caused by the four antigenically distinct dengue virus serotypes (DENV1, DENV2, DENV3, DENV4) of the family Flaviviridae are the most important arboviral diseases in humans, in terms of geographical distribution, morbidity and mortality. It is transmitted by mosquito aedes aegypti. Dengue virus infections can cause a wide clinical spectrum of disease, from a mild febrile illness known as 'denguefever' through to 'severe dengue', previously known as dengue haemorrhagic fever (DHF), which is characterized by capillary leakage leading to hypovolaemic shock, organ impairment and bleeding complications ${ }^{(1,2)}$. Clinically dengue manifests with sudden onset of high fever with chills, intense headache, muscle and joint pain, severe backache ${ }^{(3)}$. Hemorrhagic diathesis and thrombocytopenia with concurrent hemo concentration are a constant finding. The aim and objectives of the study is to determine the ultrasound findings in Dengue fever patients and their proportions. This study was performed to find whether ultrasound is an important adjunct to clinical and laboratory profile in diagnosing dengue fever. Ultrasonography (USG) is a cheap, rapid and widely available non-invasive imaging $\operatorname{method}^{(4,5)}$. To further determine whether ultrasound is useful in predicting the severity of disease.

\section{MATERIALS AND METHODS}

Present prospective study was conducted at Mamata General Hospital; all dengue serology positive cases referred by the Department of General medicine and pediatrics to the Department of Radio diagnosis in Mamata 
General Hospital, Khammam from june 2015-dec 2015. A total of 115 cases suspecting dengue, based on clinical (fever, body aches, bleeding manifestations) and laboratory profile (platelet count) will be subjected to Ultrasonography. The study was conducted using Esaote MyLab 60 and SonoScape machines. TAS examinations were carried out using curvilinear 3.5 to $5-\mathrm{MHz}$ transducers. Gallbladder wall thickening was measured by placing the calipers between the two layers of anterior wall. Liver measuring more than $15 \mathrm{cms}$ was taken as hepatomegaly and spleen more than $12 \mathrm{cms}$ was considered as splenomegaly ${ }^{(6)}$. Thoracic scanning was done in sitting or supine posture. Both the pleural spaces were evaluated through an intercoastal approach.

\section{Inclusion criteria:}

Patients of all age groups with dengue serological markers (Ns1Ag, IgM antibody, IgG antibody) positive cases

\section{Exclusion criteria:}

- All other fever cases (other than dengue)

- $\quad$ Serologically negative dengue cases

- Other conditions which predisposes to thrombocytopenia

- All other causes which predisposes to hepatospleenomegaly

- $\quad$ All other causes which predisposes to ascitis, POD collection \& pleural effusion.

- Causes of cholecystitis (calculous and other causes of acalculous)

- HELLP syndrome, which occurs in pregnent women with pre-eclampsia and eclampsia

\section{STATISTICAL ANALYSIS:}

All the data will be recorded in the proforma of the individual patients. At the end of the study, these data will be analyzed and from the results, relevant statistical data will be obtained. Total 115 seropositive cases are again dived into four groups based on their age to determine the age distribution of imaging features. Group 1 consists of patients from 0 to 20 years (41 patients), group
2 between 21 to 40 years ( 44 patients), group 3 between 41 to 60 years (27 patients) and group 4 above the age of 60 years( 3 patients).

\section{RESULTS}

Out of 115 cases 33 had Hepatomegaly (47\%) figure1, 25 had Ascitis (35.7\%) figure2, 18 had Cholecystiyis (25.7) figure3, 13 had Spleenomegaly (18.6\%), 11 had Bilateral Pleural effusion (15.7\%), 8 had Right sided Pleural effusion (11.4\%), 5 had POD collection (7.1\%), 4 had Hydronephrosis (5.7\%), 3 had Left sided Pleural effusion (4.2\%) and 48 cases has no abnormal ultrasound findings $(41.7 \%)$ table1 . 22 Cases with platelet count $>1,50,000$ shows normal ultrasound features in 16 cases $(72.2 \%)$, hepatomegaly in 4 cases $(18.2 \%)$, ascitis in $1 \operatorname{case}(4.5 \%)$ and bilateral pleural effusion in 1 case $(4.5 \%) .57$ cases with platelet count between 75,000 to $1,50,000$ shows normal ultrasound features in 21 cases $(36.8 \%)$, hepatomegaly in 17 cases $(29.8 \%)$, splenomegaly in 8 cases(14\%), ascitis in 9 cases (15.7\%), cholecystitis in 9 cases $(15.7 \%)$, POD collection in 3 cases $(5.2 \%)$, bilateral pleural effusion in 5 cases $(8.7 \%)$ and right sided pleural effusion in 5 cases $(8.7 \%)$. 16 cases with platelet count between 50,000 to 75,000 shows normal ultasound features in 3 cases (18.7\%), hepatomegaly in 6 cases $(37.5 \%)$, spleenomegaly in 1 case $(6.2 \%)$, ascitis in 5 cases $(31.2 \%)$, cholecystis in 4 cases $(25 \%)$, POD collection in 1 case $(6.2 \%)$, bilateral pleural effusion in 2 cases (12.5\%), right sided pleural effusion in 2 cases $(12.5 \%)$ and left sided pleural effusion in 2 cases (12.5\%). 20 cases with platelet count $<50,000$ shows normal ultrasound features in 5 cases (25\%), hepatomegaly in 6 cases (30\%), spleenomegaly in 4 cases $(20 \%)$, ascitis in 10 cases $(50 \%)$, cholecystitis in 5 cases( $25 \%)$,POD collection in 1 case $(5 \%)$, bilateral pleural effusion in 4 cases $(20 \%)$,right sided pleural effusion in 1 case $(5 \%)$ and left side pleural effusion in 1 case (5\%) table2. 


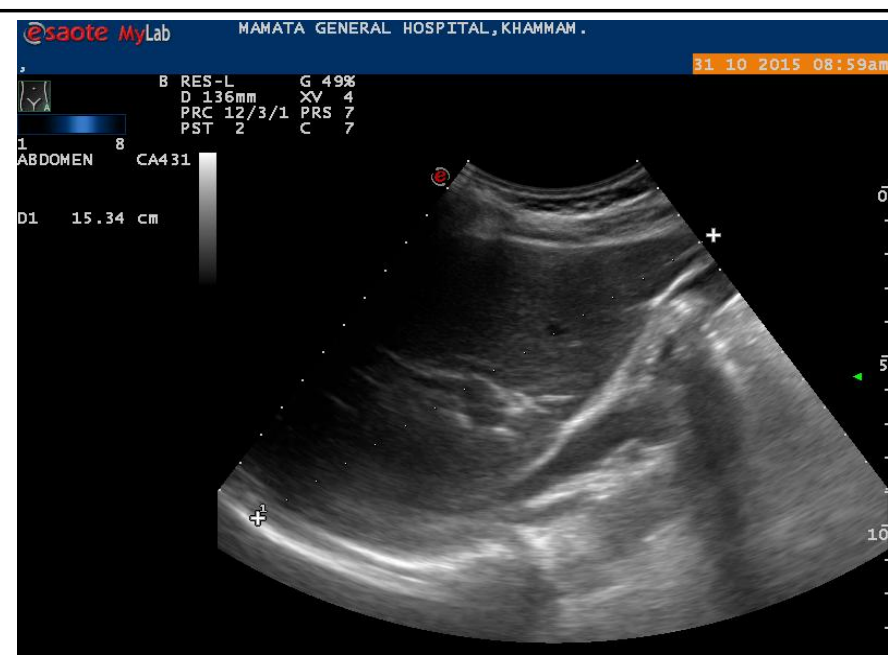

Figure 1: 28 yrs male patient with dengue fever shows mild hepatomegaly.

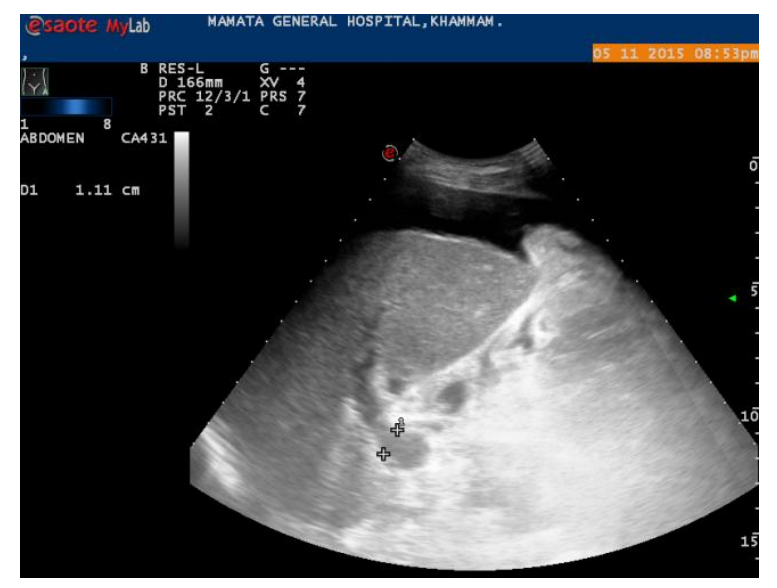

Figure 2: 33 years female patient with dengue fever shows Ascitis

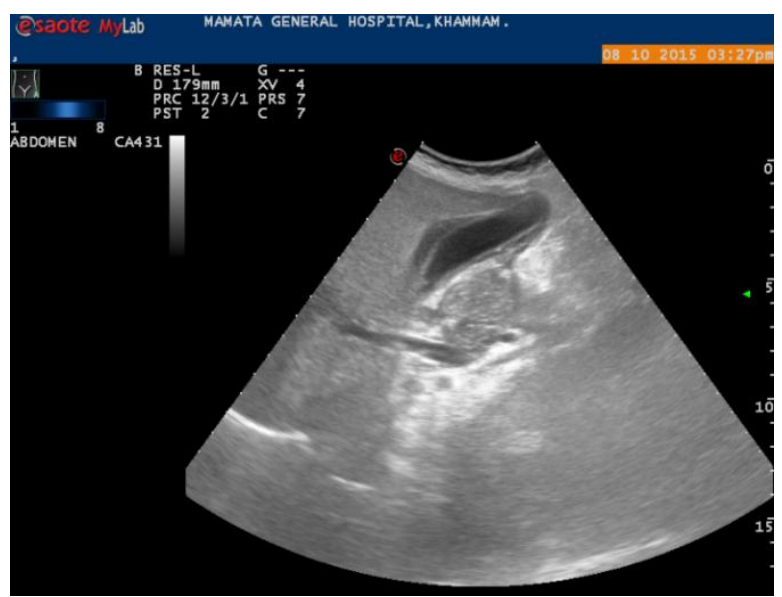

Figure 3: Ultrasound liver through right hypochondrium shows thick wall gall bladder with minimal pericholecystic fluid.

TABLE 1: Ultrasound features in our study

\begin{tabular}{|l|c|}
\hline FINDING & NUMBER OF CASES \\
\hline Hepatomegaly & $33(47.1)$ \\
\hline Spleenomegaly & $13(18.6)$ \\
\hline Ascitis & $25(35.7)$ \\
\hline Cholecystitis & $18(25.7)$ \\
\hline Pod collection & $5(7.1)$ \\
\hline Bilateral pleural effusion & $11(15.7)$ \\
\hline Right pleural effusion & $8(11.4)$ \\
\hline Left pleural effusion & $3(4.2)$ \\
\hline Hydronephrosis & $4(5.7)$ \\
\hline Total number of cases & 70 \\
\hline
\end{tabular}

TABLE 2: Clinical Findings In Corelation With Platelet Count.

\begin{tabular}{|c|c|c|c|c|c|c|c|c|c|c|}
\hline $\begin{array}{l}\text { Platelet } \\
\text { Count }\end{array}$ & $\begin{array}{c}\text { Total } \\
\text { number } \\
\text { of cases }\end{array}$ & Normal & $\begin{array}{l}\text { Hepato } \\
\text { Megaly }\end{array}$ & $\begin{array}{l}\text { Spleeno } \\
\text { Megaly }\end{array}$ & Ascitis & $\begin{array}{c}\text { Chole } \\
\text { Cystitis }\end{array}$ & $\begin{array}{c}\text { POD } \\
\text { Collection }\end{array}$ & Bilateral pleural effusion & $\begin{array}{c}\text { Right } \\
\text { pleural } \\
\text { effusion only }\end{array}$ & $\begin{array}{l}\text { Left pleural } \\
\text { effusion }\end{array}$ \\
\hline$>1,50,000$ & 22 & $16(72.2)$ & $4(18.2)$ & 0 & $1(4.5)$ & 0 & 0 & $1(4.5)$ & 0 & 0 \\
\hline $75,000-1,50,000$ & 57 & $21(36.8)$ & $17(29.8)$ & $8(14)$ & $9(15.7)$ & $9(15.7)$ & $3(5.2)$ & $5(8.7)$ & $5(8.7)$ & 0 \\
\hline $50,000-75,000$ & 16 & $3(18.7)$ & $6(37.5)$ & $1(6.2)$ & $5(31.2)$ & $4(25)$ & $1(6.2)$ & $2(12.5)$ & $2(12.5)$ & $2(12.5)$ \\
\hline$<50,000$ & 20 & $5(25)$ & $6(30)$ & $4(20)$ & $10(50)$ & $5(25)$ & $1(5)$ & $4(20)$ & $1(5)$ & $1(5)$ \\
\hline
\end{tabular}

TABLE 3: Incidence Of Sonographic Findings In Relation To Different Age Groups

\begin{tabular}{|l|c|c|c|c|c|c|c|c|c|c|}
\hline Age & $\begin{array}{c}\text { Total number of } \\
\text { Cases }\end{array}$ & Normal & $\begin{array}{c}\text { Hepato } \\
\text { Megaly }\end{array}$ & $\begin{array}{c}\text { Spleeno } \\
\text { megaly }\end{array}$ & Ascites & $\begin{array}{c}\text { Chole } \\
\text { Cystitis }\end{array}$ & POD collection & $\begin{array}{c}\text { Bilateral pleural } \\
\text { effusion }\end{array}$ & $\begin{array}{c}\text { Right pleural } \\
\text { effusion }\end{array}$ & $\begin{array}{c}\text { Left pleural } \\
\text { effusion }\end{array}$ \\
\hline $0-20$ & 41 & $\begin{array}{c}15 \\
(36.5)\end{array}$ & $\begin{array}{c}10 \\
(24.4)\end{array}$ & $\begin{array}{c}3 \\
(7.3)\end{array}$ & $\begin{array}{c}15 \\
(36.5)\end{array}$ & $\begin{array}{c}10 \\
(24.4)\end{array}$ & $2(4.8)$ & $\begin{array}{c}6 \\
(14.6)\end{array}$ & $\begin{array}{c}5 \\
(12.1)\end{array}$ & $1(2.4)$ \\
\hline $21-40$ & 44 & $\begin{array}{c}19 \\
(43.1)\end{array}$ & $\begin{array}{c}11 \\
(26.8)\end{array}$ & $\begin{array}{c}8 \\
(18.2)\end{array}$ & $\begin{array}{c}8 \\
(18.2)\end{array}$ & $\begin{array}{c}7 \\
(15.9)\end{array}$ & $4(9.1)$ & $\begin{array}{c}5 \\
(10.4)\end{array}$ & $2(4.5)$ \\
\hline $41-60$ & 27 & $\begin{array}{c}12 \\
(44.4)\end{array}$ & $\begin{array}{c}11 \\
(40.7)\end{array}$ & $\begin{array}{c}2 \\
(7.4)\end{array}$ & $\begin{array}{c}2 \\
(7.4)\end{array}$ & $\begin{array}{c}1 \\
(3.7)\end{array}$ & 0 & 0 & $1(2.3)$ \\
\hline $61-80$ & 3 & $\begin{array}{c}2 \\
(66.6)\end{array}$ & $\begin{array}{c}1 \\
(33.3)\end{array}$ & 0 & 0 & 0 & 0 & 0 & $1(3.7)$ & $1(3.7)$ \\
\hline
\end{tabular}


The findings regarding age distribution of imaging are:

- Hepatomegaly is common in group 3 than other groups.

- $\quad$ spleenomegaly is commom in group 2.

- Ascitis and cholecystitis are common in group 1 than other age groups.

\section{Combination of imaging features:}

- Ascitis, Cholecystitis and Bilateral pleural effusion are more common in group 1table 3.

\section{Correlation with platelet count:}

- Cholecystistis is seen more common in patients with platelet count less than $50,000(25 \%)$, and also between 50,000 to $75,000(25 \%)$.

- Ascitis (50\%), Bilateral pleural effusion(20\%) and spleenomegaly (20\%) are most commonly seen in patients with platelet count less than 50,000 .

- Hepatomegaly $(37.5 \%)$ is more commonly seen in patients with platelet count between 50,000 to 75,000 .

\section{DISCUSSION}

The name dengue originated from the Swahili word for "bonebreaking fever" or the word for "the walk of a dandie" in Spanish. The first probable case of dengue fever (DF) was recorded during the Jin Dynasty (265-420 AD) in China. The first recognized epidemics occurred almost simultaneously in Asia, Africa and North America in the 1780s, shortly after the identification and naming of the disease in 1779 by Benjamin Rush (7). The incidence of dengue has grown dramatically around the world in recent decades. One recent estimate indicates 390 million dengue infections per year $(95 \%$ credible interval $284-$ 528 million), of which 96 million (67-136 million) manifest clinically (with any severity of disease) ${ }^{(8)}$. Presently, about $40 \%$ of the world's population is at risk and there are 50-100 million cases every year. An estimated 500000 people with severe dengue require hospitalization each year and about $2.5 \%$ of those affected die ${ }^{(9)}$ In India, dengue is widespread and endemic in most major cities ${ }^{(10)}$. Dengue virus is transmitted from human to human by different species of Aedes mosquitoes.The strong association between the development of severe disease in secondary dengue and the observation that complications occur when the viraemia is in steep decline, has led to the suggestion that the pathogenesis of severe dengue is immunemediated. Halstead in the 1970 s proposed the 'antibody-dependent immune enhancement theory' (ADE) based on in vitro and primate studies $^{(11)}$. This association of sequential dengue infections being a risk factor for severity has been confirmed repeatedly in epidemiological studies, from different parts of the world ${ }^{(12,13)}$. In addition, a particular sequence of infecting serotypes have been linked to severe disease, with several studies suggesting severe dengue is more common in a secondary infection with DENV2 ${ }^{(14,15)}$. During the second infection with a different dengue serotype, pre-existing antibody from the first infection fails to neutralize and may instead enhance viral uptake and replication in mononuclear cells ${ }^{(16)}$. The resulting higher viral load has been linked to disease severity ${ }^{(17)}$. Other factors that may contribute to the pathogenesis of severe dengue include more virulent strains of the virus ${ }^{(18)}$, host genetic factors, age and comorbidities ${ }^{(19-21)}$.

\section{Significant changes are found in major organ Systems(22)}

1. Vascular changes include vasodilatation, congestion, perivascular haemorrhage and oedema of arterial walls

2. Proliferation of reticuloendothelial cells with accelerated phagocytic activity is observed frequently

3. The lymphoid tissues show increasing activity of the B lymphocyte system with active proliferation of plasma cells and lymphoblastoid cells 
4. In the liver there is focal necrosis of the hepatic and Kupffer cells, with formation of Councilman-like bodies

5. Dengue virus antigen is found predominantly in cells of the spleen, thymus and lymph nodes, in Kupffer cells and in the sinusoidal lining cells of liver and alveolar lining cells of the lung.

The pathophysiological hallmarks of severe dengue are plasma leakage and abnormal haemostasis. Clinical evidence supporting plasma leakage includes a rapid rise in haematocrit, hypoproteinaemia, pleural effusions and ascites and reduced plasma volume, leading to haemodynamic compromise and hypovolaemic shock. Age-related changes occur in microvascular permeability, with children having higher filtration capacity than adults, which would explain why dengue shock syndrome is more common in childhood ${ }^{(23)}$.

\section{Warning Signs(2009WHO GUIDE LINES)}

1. Abdominal pain or tenderness

2. Persistent vomiting

3. Clinical fluid accumulation

4. Mucosal bleed

5. Lethargy/restlessness

6. Liver enlargement $>2 \mathrm{~cm}$

7. Laboratory increase in HCT concurrent with rapid decrease in platelet count

Early diagnosis of dengue virus (DENV) infection can improve clinical outcomes by ensuring close follow-up, initiating appropriate supportive therapies and raising awareness to the potential of hemorrhage or shock. Serology is the mainstay in the diagnosis of DF, positive serology (anti dengue antibody) is the mainstay in the diagnosis of DF. Haemagglutination inhibition antibodies usually appear at detectable level by day 5 to 6 of febrile illness. Non-structural glycoprotein-1 (NS1) has proven to be a useful biomarker for early diagnosis of dengue ${ }^{(24)}$. The acquired immune response following a dengue infection consists of the production of $\operatorname{IgM}$ and $\operatorname{IgG}$ antibodies primarily directed against the virus envelope proteins. Ultrasound abdomen and horax findings in early, milder form of dengue fever include GB wall thickening, minimal ascites, pleural effusion and hepato-splenomegaly. Severe forms of the disease are associated with the collection of fluid in the perirenal and pararenal regions, hepatic and splenic subcapsular fluid, pericardial effusion, pancreatic enlargement and hepato-splenomegaly. Due to intraparenchymal and sub capsular hemorrhages, there will be an alteration in the normal liver echo texture ${ }^{[25,26]}$. However, in our study, we did not find any of the above-mentioned sonographic features even in severe forms of dengue fever except hepatosplenomegaly. GB wall thickening also occurs in association with other conditions such as ascites, hypoalbuminemia, congestive cholecystopathy and in patients with cirrhosis of liver and portal hypertension. It is a very nonspecific finding when considered in isolation and is therefore a major limitation of this study. Imaging features of dengue fever such as GB wall thickening, ascites, pleural effusion, hepatomegaly and splenomegaly are reasonably accurate in the diagnosis of dengue fever. This helps in starting appropriate management of the patient as soon as ultrasound is done, especially in centers where high end laboratory facilities may not be available for serological confirmation. While serological tests are confirmatory in the diagnosis of dengue fever, ultrasound can be of value in the assessment of severity. In a similar study conducted in 2012 by Santosh et al., the most common age group affected is $21-40$ years like in our study table 3 . In that study edematous GB wall thickening was the most common finding $(66.7 \%)$ but in our study hepatomegaly is the most common finding (47.1\%). In their study ascitis is seen in $64.5 \%$ but in our study it is seen in $35.7 \%$ and is the second most common finding. The severity is related to platelet count where more than three abnormal sonographic features are seen when count is less than 40,000 . 


\section{CONCLUSION}

Ultrasound features like cholecystitis, ascitis, pleural effusion (bilateral or right sided), hepatomegaly, and spleenomegaly strongly favor the diagnosis of dengue fever. sonographic features are also helpful in estimating the severity. The degree of thrombocytopenia shows a direct relationship to abnormal sonographic features.

\section{REFERENCES}

1. Simmons CP, Farrar JJ, Nguyen VV, et al.: Dengue. $N$ Engl J Med.366:142314322012

2. WHO: Dengue: Guidelines for Treatment, Prevention and Control. 2009World Health Organization Geneva

3. New Delhi: Ministry of Death and Family Welfare; 2006. Internet,Government of India. National Vector Bourne Disease Control Programme

4. Venkata S, Dev B, Krishnan R. Role of ultrasound in dengue fever. Br J Radiol. 2005;78:416-18.

5. Thulkar S, Sharma S, Srivastava DN et al. Sonographic findings in grade III dengue hemorrhagic fever in adults. $J$ Clin Ultrasound 2000; 28: 34-7.

6. Konus OL, Ozdemir A, Akkaya A, Erabas G, Celik H, Isik S. Normal liver, spleen and kidney dimensions in neonates, infants and children: Evaluation with sonography. AJR Am J Roentgenol. 1998;171:1693-8.

7. Halstead SB. Dengue (Tropical Medicine: Science and Practice). River Edge, N.J: Imperial College Press. 2008. pp. 1-10.

8. Bhatt S, Gething PW, Brady OJ, Messina JP, Farlow AW, Moyes CL et.al. The global distribution and burden of dengue. Nature;496:504-507

9. World Health Organization. Dengue and severe dengue. Fact sheet no. 117, March 2014. Geneva: WHO, 2014. http://www.who.int/ mediacentre/fact sheets/fs117/en/ - accessed 16 March 2014
10. National Vector Borne Disease Control Programme. Dengue/ dengue haemorrhagic fever. 2013. http://www.nhp gov.in/ nvbdcp - accessed 16 March 2014

11. Halstead SB, O'Rourke EJ: Antibodyenhanced dengue virus infection in primate leukocytes. Nature. 265:739-741 1977

12. Sangkawibha N, Rojanasuphot S, Ahandri $\mathrm{kS}$, et al.: Risk factors in dengueshock syndrome: a prospective epidemiologic study in Rayong, Thailand. I. The 1980 outbreak. Am J Epidemiol.120:6536691984

13. Guzman MG, Kouri G, Valdes L, et al.: Epidemiologic studies on Dengue in Santiago de Cuba, 1997. Am J Epidemiol. 152:793-799 2000

14. Thein S, Aung MM, Shwe TN, et al.: Risk factors in dengue shock syndrome. Am J Trop Med Hyg. 56:566-572 1997

15. Burke DS, Nisalak A, Johnson DE, et al.: A prospective study of denguein fections in Bangkok. Am $J$ Trop Med Hyg. 38:172-180 1988

16. Halstead SB: Pathogenesis of dengue: challenges to molecular biology. Science. 239:476-481 1988

17. Solomon T, Dung NM, Vaughn DW, et al.: Neurological manifestations of dengue infection. Lancet. 355:1053-1059 2000

18. Rico-Hesse R: Dengue virus evolution and virulence models. Clin Infect Dis.44:146214662007

19. Loke H, Bethell DB, Phuong CX, et al.: Strong HLA class I-restricted $\mathrm{T}$ cell responses in dengue hemorrhagic fever: a double-edged sword? J Infect Dis. 184:1369-1373 2001

20. Coffey LL, Mertens E, Brehin AC, et al.: Human genetic determinants of denguevirus susceptibility. Microbes Infect. 11:143-156 2009

21. Loke H, Bethell D, Phuong CX, et al.: Susceptibility to dengue hemorrhagic fever in Vietnam: evidence of an association 
with variation in the vitamin $\mathrm{D}$ receptor and Fc gamma receptor IIa genes. Am J Trop Med Hyg. 67:102-106 2002

22. Bhamarapravati N, Tuchinda P, Boonyapa knavik V: Pathology of Thailand haemorrhagic fever: a study of 100 autopsy cases. Ann Trop Med Parasitol.61:500-510 1967

23. Gamble J, Bethell D, Day NP, et al.: Agerelated changes in microvascular permeability: a significant factor in the susceptibility of children to shock? Clin Sci (Lond). 98:211-216 2000

24. valuation of Dengue NS1 Antigen Rapid Tests and ELISA Kits Using Clinical Samples - Subhamoy Pal, Allison L. Dauner, Indrani Mitra, Brett M. Forshey, Paquita Garcia, Amy C. Morrison,Eric S. Halsey, Tadeusz J. Kochel, and ShuennJue L. Wu1

25. Joshi P, Ratnam VG, Sharma S USG findings in dengue haemorrhagic fever our experience in the recent epidemic, Indian J Radiol Imaging. 1997;7:189-92

26. Venkata Sai, Dev B, Krishnan R- Role of ultrasound in dengue fever. 